ELORE (ISSN 1456-3010), vol. $13-1 / 2006$.

Julkaisija: Suomen Kansantietouden Tutkijain Seura ry. Taitto: Jukka Talve. [http://cc.joensuu.fi/ /oristi/1_06/hin1_06.pdf]

\title{
Latvian-Americans in the Post-Soviet Era: Cultural Factors on Return Migration in Oral History INTERVIEWS
}

\author{
Maija Hinkle
}

International population migration has been the focus of intense research, numerous governmental and academic studies and declarations (1), theoretical considerations (see Cassarino 2004), and many conferences for at least half a century. Only about 10 percent of this effort has been directed at documenting and understanding the multifaceted and heterogeneous phenomenon of return migration or transmigration, even though repeat migrations and the formation of transnational communities and identities (see Takenaka 1999) is becoming increasingly common in the last few decades. A great majority of the studies have dealt with economic migrants, people who leave their country to try to secure a more stable economic future. Much less attention has been paid to the other migratory categories such as political refugees and asylum seekers. This article will focus on a small subset of potential international return migrants, World War II refugees from Latvia, who emigrated to the United States around 1950.

When the Soviet Army returned to Latvia and absorbed it into the Soviet Union in 1944, about a tenth of the population (some 200000 people) left Latvia for the West. After refugee camps in Germany, the largest number (40 000) eventually settled in the United States (Plakans 1995) (2), where many established Latvian emigre communities. These communities were defined mainly by their common heritage and language, not necessarily by geographical space. Their two main goals were to remind the world about Latvia's occupation and to preserve Latvia's prewar culture, language and values. In the 1989 census slightly more than 100000 American inhabitants listed their ancestry as Latvian. (Carpenter 1996, 93.)

Just as World War II was accompanied by a mass migration of peoples across Europe and elsewhere, so the collapse of the Soviet Union in 1989-1991 created an opportunity for return migration for peoples who had been displaced by political forces during the conflict more than half a century before. The potential return migration of Latvian-Americans, however, has not materialized in anywhere 
near the volume that either the government of Latvia or the leaders of the emigre community had hoped for or anticipated. This study will attempt to understand some of the reasons for the lack of return migration.

Since life in Soviet Latvia was very different from that in Latvian-American communities, and since contacts between the two sides were by necessity very limited, especially from the Soviet side, the two communities had developed very different lifestyles, expectations, and coping strategies. In addition, many in the emigre community saw themselves as the true embodiment of Latvian identity, rather than the people in Latvia, since in Soviet Latvia, this was being suppressed and distorted. (Carpenter 1990.) Thus it is hardly surprising that the first euphoria after independence in 1991 (Carpenter 1996, 93), soon turned into mutual disappointment and even rejection that is only now starting to dissipate. The newly regained Latvian independence forced members of the exile community to re-evaluate their relationship both to Latvia and to their adopted country, America, because with Latvia's independence the émigré communities lost the main reasons for their very existence.

Qualitative biographical methods in the form of life story narratives and oral history interviews can have a valuable role not only in probing motivations, but also in émigré identity re-evaluation and, in a small way, in processes of reconciliation and bridge-building. Oral history testimonies expand our knowledge and understanding of historical events. In dealing with the "why and how," as opposed to the "when, who, where" of documentary history, they reveal the reasons and motivations behind events and decisions. They also have a psychological dimension that has an effect on both the narrator and the listener. As Rosenwald \& Ochberg have argued, life review in a crossroads situation, such as the one that the diaspora Latvian-Americans are facing, helps an individual to decide on his/her future path (Rosenwald \& Ochberg 1992). Finally, life stories help members of disparate groups, such as Latvians in Latvia and members of the diaspora, to understand one another better, and to empathize with members of the other group (see Clarke 2002). As the then graduate student at the University of Latvia, Baiba Bela-Krūmina, said after listening to the life stories of twenty-four Latvian-Swedes, "Only now I am starting to understand what it meant to be a refugee and an exile". I have felt the same way after recording life stories in the Latvian countryside.

In what follows I will focus on the changing relationship of Latvian-Americans to Latvia and to their emigre Latvian identity, as revealed in life story narratives of individuals from the community between 1997 and 2004. I will first outline briefly the reasons that people gave for leaving Latvia, and for staying connected to Latvian culture and community throughout their exile. The bulk of the article is then devoted to the Post-Soviet situation and the cultural factors that hamper understanding between Latvian and diaspora communities and sometimes inhibit return migration to Latvia. Subsequent papers will be used to discuss emigres who have successfully remigrated to Latvia, and strategies that Latvian-Americans have used to contribute to the development and culture of Latvia without actual remigration. 
MAJJA HinKLE

\section{DOCUMENTING THE EMIGRE EXPERIENCE}

In 1997, Professor Inta Gāle Carpenter and I began to conduct an oral history project among Latvian-Americans under the sponsorship of the American Latvian Association (ALA). The aim of the project is to document the exile experience and to try to build bridges between the Latvian and exile communities. By collecting as many Latvian-American life stories as possible, it also seeks to add these stories to the American immigration experience, as well as to integrate them into the history of the Latvian people. Since the methods, results, and outreach in our project have already been outlined elsewhere (Hinkle 2005), I will just briefly recap some of the most salient points here.

Almost all of the interviewing, organizational and outreach work in the project is done by trained volunteers, and after a joint training program, interviewers work relatively independently, each in his or her own community. Interviewer training therefore forms an important part of the project. To date we have trained 162 potential volunteers, thirty-two of whom have recorded one or more interviews.

Although we allow each interviewer to choose the narrators, we recommend that interviewers start with older people, who may have significant knowledge of or participation in historical events, or who have contributed to their community or culture. Consequently, most of our authors have been active, valuable members of their community or profession. Although we do have topics that we would like all interviewers to cover (for example, the narrators' self-identification, reasons for leaving Latvia, relationship to American society), we generally allow the narrator to lead the story and choose the topics which he or she would like to emphasize.

We have recorded about 220 life narratives from one to twenty hours in length, for a total of about 500 hours. Most narratives are about two hours long, some are much longer. Most are in Latvian, but two are in English, one in German. Almost all narratives are from first generation refugees of World War II $(85 \%)$ or from their second generation descendants (12\%), a few are with Latvian Jews, a Baltic German and an American. A great majority (about three quarters) of the narrators were over 70 years old, about $17 \%$ were in their sixties and the rest were younger - in their fifties or fourties.

The narrative texts are available at the University of Latvia, and will be deposited at the Immigration History Research Center at the University of Minnesota in Minneapolis, MN. All narratives have basic documentation, and a summary of narrative contents. Some outlines are on the internet at the Latvian National Oral History project website (<www.dzivesstasts.lv>). Descriptions of the Latvian life story project and collection can also be found on the website, along with various links. Many interviews have been transcribed, and some have been translated into English. 


\section{Latvian-Americans in the Post-Soviet Era}

\section{LeAving LATVIa}

Since Jean-Pierre Cassarino proposed that for a successful return migration the reasons for the initial immigration and the intended length of stay are of great importance (Cassarino 2004), we asked all of our narrators why they left Latvia. Almost all the civilians who fled their homes said that they left because they were afraid of the Russians coming back and that the mass deportations will recur. Some also mentioned bombing; some the fact that their homes had already been destroyed. Others had gone to work in Germany.

Whatever the immediate reason for leaving their home, all narrators said that they thought that the leaving will be temporary, that they would be able to return soon: "The whole war-time was horrible. But the most terrible thing was that we had to leave our home, that we had to leave our home and go away. We never thought that we'd have to leave our country, never, never, never. We didn't think that we'd have to leave." (Interview of Lidija Bālēna, 2000.) Rita Drone related how her mother had paid their landlord a whole year's rent in advance because "She wanted the apartment to be there for them when she came back" (Interview of Rita Drone, 2005).

Even though leaving home and Latvia was always very painful for the adults (although not necessarily for the children, who sometimes saw it as a great adventure) (Interview of Andrejs Jansons, 1999), for many leaving Europe to go to the United States was equally traumatic. Once again, however, there were exceptions, particularly among children for whom it could be exciting and enticing.

After arrival in the United States (most of the refugees from Germany arrived between 1949-1952), the refugees developed variable relationships to their home country. While some assimilated into American culture and society, others developed communities-in-exile, for which the psychological and practical groundwork had already been laid in the five to six years in Displaces Persons (DP) camps in Germany. The close contacts between people in the camps had already created the beginnings of a transnational social network that could be activated once the refugees arrived in the United States. Some large scale organizations, such as the veterans' organization, Daugavas Vanagi, had also been founded. (See Wyman 1998.) One of the participants in my workshop on "Exile History," held in the Catskills in August, 2005, commented as follows:

If we hadn't had the experience of the camps, [..] if we hadn't had schools, [..] scouts,
who had a very powerful nationalistic bent, [..] if we hadn't had camp classmates whom
we could write to and visit in Boston, Chicago, Washington, [..] we would never have
remained Latvians for so long. We would've joined American society much earlier.
("Exile History" workshop, 3x3 Catskills, NY, 2005.)

Furthermore, in Germany and during the first years in the United States a more or less unified, powerful narrative about the collective experiences of exile had emerged. The underlying theme of this narrative - one that very quickly became transformed into a mission - was that Latvians in America are duty bound to preserve their na- 


\section{MAJJA HinKLE}

tional identity, and pass it on to future generations (Carpenter 1990), that they, the emigres rather than the people who had stayed behind, embodied the true Latvian "soul" and identity. This sense of duty or mission generated much positive, creative energy for the formation of organizations, new institutions, and programs, but it also served to isolate the emigres from American society and culture, and created a rather inflexible framework for correct behavior that eventually caused great strains and divisions within the communities. Mark Wyman describes group solidarity among the Baltic emigres as follows:

A Canadian investigator found that while Baltic girls were crossing the ocean to Canada, presumably to become Canadian, they did not attempt to mix with other immigrant groups but filled their shipboard life with close identificaiton with members of their own ethnic group - through folk dancing, ship newspapers, talking, even flirting. (Wyman 1998, 206.)

When in 1990 I asked the ALA about Latvian-American organizations in the US, I was told that there were still more than 500 organizations! Many of our narrators have been part of this active Latvian community. In the words of Ādolfs Ābele from Los Angeles: "Just like everywhere else, we started organizing. As soon as I had found a job, I also started working in our community. We organized a church." (Interview of Ādolfs Ābele, 1999.)

I wanted to use our in-depth life story interviews to probe deeper into the narrators' motivations for retaining their Latvian identity and staying connected to their Latvian community over many years. Was it really the sense of duty or mission that was the primary motivator or was it something else? When asked why they had remained connected to Latvian society and culture, most of our narrators, especially from the older generation, simply said: "Jo es citādi nevaru" [Because I can't do otherwise] often with a look of exasperation at such an obvious question. But if I looked a little deeper for what that meant, I discovered several distinct reasons.

In the first place, many narrators did seem to feel a deep sense of responsibility toward Latvia and the people who remained there. One, Maija Medne, said that she had to retain her identity "Because I had to keep Latvia alive (in the sense of maintaining it). I had a feeling that I had to do this, that it was my responsibility. [... I'm very glad that my children speak Latvian" (Interview of Maija Medne, 1998). Latvia itself had to "be kept alive" by the fact that she and other young people remained Latvian, that they created an active community and culture, that they spoke 
Latvian, that they danced Latvian folk dances and sang Latvian folk songs, and raised Latvian-speaking children and grandchildren, even though they did this while living in exile. Another, Miervaldis Janšēvics, states that:

\begin{abstract}
I was terribly upset about Russification in Latvia. I was very surprised that the independence of Latvia arrived so soon. I thought that when it comes, no Latvian-speakers will be left and the Russians will have won. We had to decide whether Latvian culture should continue to exist or not. (Interview of Miervaldis Janšēvics, 1998.)
\end{abstract}

Thus, for many narrators the sense of responsibility that it was up to them to keep Latvia alive was indeed the primary motivator for remaining active in Latvian society and culture.

But there were other reasons as well, perhaps just as powerful. The Latvian community and other Latvians offered purely practical help to each other, especially in the beginning, with housing, advice and money. In the words of Lidija Bālenna: "We were let out on the New York docks; everybody else had someone to greet them, we had nobody. We had no money, no language. But they had arranged that we could stay at my husband's cousins. And so we did." (Interview of Lidija Bālēna, 2000.) Help in even greater amounts came through organizations. For example, Kārlis Kuzulis describes the results of fundraising activities in 1952 on behalf of an injured war veterans' home in Germany: "At that time nobody had much money and donations arrived in amounts of one or two dollars. You can imagine how many people donated, because we collected the vast sum of $\$ 30,000$ from people who essentially had nothing.” (Interview of Kārlis Ķuzulis, 2000; Zirnite \& Hinkle 2005, 168-200.) Unlike most other immigrants to the United States, the refugees did not send any remittances back to their home country, at least not in the beginning, because to receive packages or money from abroad in the Stalinist Soviet Union would have been dangerous for the recipients.

Furthermore, people wanted to enjoy their own culture and language, which was familiar and in which they felt at home. For example, Baiba Dumpe describes her wedding with both Latvian and American guests:

After the wedding we had a celebration together with the American guests, all kinds
of food, but only with lemonade, coffee or tea [..]. Everyone couldn't wait for the
Americans to leave, so we could start celebrating for real. Then we had the Latvian
festivities. We'd killed a pig, since it was out in the country. (Interview of Baiba
Dumpe, 1999-2001; Zirnite \& Hinkle 2005, 209.)

There were also more selfish reasons for remaining in Latvian society, especially in the beginning, when it was a way to show off, to gain prominence, something which was not yet possible in American society. According to Ādolfs Ābele: "People fought with each other for prominent positions [in organizations]. There were all kinds of former directors of this, that or other, who wanted to gain jobs and titles, because 
they thought that they will soon go back to Latvia and then they would be leaders there, too." (Interview of Ādolfs Ābele, 1999.) In the last 25 years this has changed, and diaspora Latvian organizations often have trouble finding officers willing to put in the necessary work and take on responsibilities.

Interestingly, even though nobody in individual interview situations gave a negative reason for remaining connected to the Latvian culture and community (for example, that Americans don't accept them or that they felt excessively pressured by the Latvian community or their family to remain Latvian), several participants in my "Exile History" workshop recounted very unhappy and traumatizing experiences occasioned by the rigid demands for correct behavior in émigré Latvian society. This was particularly with respect to marriage with Americans and acceptance by a new community. ("Exile History" workshop, 3x3 Catskills, NY, 2005.) The very positive individual evaluations and memories could have several explanations. Perhaps the fact that Latvia is now independent and their work has borne fruit may color their memories of the past. Also our narrator sample probably skewed the results, because we recorded stories primarily from people who had remained active participants in émigré culture and had not been driven away. (3) Furthermore, for the generation of most of our narrators, who arrived in the United States as young adults or children, acceptance by Americans really was not a problem, the major problem for some were the strictures put upon them by Latvian society.

To summarize, for many narrators staying connected to their Latvian community and culture was not only a duty and a responsibility, but also entailed positive rewards - a familiar culture and many cultural activities, a ready-made social and sometimes even an economic network, transnational connections, community recognition, sometimes enhanced educational opportunities - besides the satisfaction that comes from fulfilling one's obligations.

\section{The RELATIONSHIP to LATVIA}

Although the active Latvian-Americans had a very clear Latvian identity, different individuals and groups developed quite different attitudes towards Soviet-occupied Latvia, which sometimes led to extremely bitter and hostile conflicts within the exile community. (4) Most members of the exile community - even if they probably would not admit it about those in opposing camps - nevertheless appeared to share a single goal, namely, a free and independent Latvian state, with the at first openly declared and later supposedly universally accepted official corollary that "when Latvia is again independent, we will all go back home". Yet when the Soviet Union collapsed and Latvia did become independent again in 1991, relatively few individuals moved back. What happened? 
The former President of the World Federation of Free Latvians, Kārlis Kouzulis, explained:

\begin{abstract}
[Although] we had always said that we are ready to return to Latvia even with bare feet, if only it were independent, [..] when this moment had arrived, and we were asked to fill three posts in the newly formed Supreme Council of Ministers in Latvia, we could find only one man, and that was Valdis Pavlouskis, who was willing to give up his job in the United States, move to Latvia and get to work. [..] The period of exile had simply been too long to keep the love and enthusiasm alive. [..] Still there are many who have returned and work there. I say this with great respect for the younger generation, because they are mostly the ones who went, basically those who had not yet started their careers here. (Interview of Kārlis Kuzulis, 2000; Zirnite \& Hinkle 2005, 155-184.)
\end{abstract}

We asked all our narrators how they define themselves now. Are they still exiles, or Latvian-Americans or diaspora Latvians, or what? Will they return home to Latvia to live, and if not, why not? Where do they feel at home? Where do they belong? This part of the study is based on the approximately 220 life narratives that we have recorded, and on focused discussions among 54 participants of oral history training workshops, where the question of identity and belonging often elicited painful and deep discussions.

A few narrators declared that they lack any sense of home or belonging and basically do not miss it. But for many narrators, especially those from the older generation, the question of home and belonging was a very painful and difficult problem. For instance, Dzidra (age 74), observed that "I truly feel like I'm split in half. When I return to America after a visit to Latvia, I feel like one half of me stays there and one half is here". (Interview of Dzidra Ziedone, 1998.)

For most narrators the reasons for not returning to Latvia to live are practical in nature. Many don't have any relatives left in Latvia, and their immediate families - their children and grandchildren - have established their lives in the United States and their parents or grandparents don't want to leave them. Some grandmothers consider their duty to teach their American-born grandchildren about Latvia. (See for example the interview of Rita Petričeks, 1999.) Some people have health problems that cannot be properly treated in Latvia. (See the interview of Oskars Hercs, in Zirnite \& Hinkle 2005.)

But there are several more complicated psychological, sociological and cultural reasons that people give for not returning to Latvia permanently. These are: firstly, the dissonance between the reality of present-day Latvia and the idealized version that some émigrés carried in their hearts throughout the period of exile; 


\section{MAJJA HiNKLE}

secondly, misunderstandings and sometimes rejection between the diaspora and Latvian communities; and thirdly, the cultural differences between the diaspora and Latvian communities, that have developed through the fifty years of separation and living in very different societies.

\section{REJECTION AND MISUNDERSTANDING BETWEEN DIASPORA AND LATVIAN COMMUNITIES}

Some narrators (and especially workshop participants, who reinforced each other; see also Kirss 2003) said that they cannot return to Latvia permanently, because they are not accepted in Latvia, are not wanted, and feel rejected. In the words of one workshop participant:

I was struck by how often people in Latvia use the phrase, "you and we", much more so than we, on our side of the ocean. We want to feel as one community more, one people, and use the term "we" even to include Latvian Latvians, but they always say: "You can't understand it." That's the constant refrain: "You can't understand. You haven't experienced it." (Oral History workshop in 3x3 camp in Elka Park, Catskills, N.Y. Aug. 2000.)

Kārlis Ķuzulis, for his part, observed that:

There are always ebbs and flows. Right in the beginning there was a time when we were greatly admired and welcomed in Latvia - all who went there, visited. But then something happened. Perhaps when the 18 deputies from the West who were elected to the Latvian "Saeima" ["parliament'] didn't accomplish what the Latvian Latvians had hoped. With that the enthusiasm for Western Latvians suddenly disappeared. "You don't do anything either, just like the politicians here." For a while the rejection and use of "you and we" was very strong, but now it's starting to abate a little. (Interview of Kārlis Ķuzulis, 2000.)

Interestingly, Professor Alexander von Plato describes a similarly complex and shifting dynamic in the relationship between East and West Germans after reunification, where initial euphoria and mutual admiration soon turned to criticism and rejection, with a partial return to pre-unification values and institutions by the East Germans. (von Plato 2003.) The Czech writer Milan Kundera (2002) presents a similarly complex and multi-layered dynamic in his novel Ignorance, in which an émigré from Czechoslovakia returns to her native country after 20 years of exile in Paris and finds that no one is interested in her experience and that she can truly communicate only with another émigré. The title of Kundera's novel points to one of the most fundamental problems underlying both these cases, namely profound mutual ignorance, incorrect assumptions by each side about the other, and unattainable expectations that stem 
from this. Kundera's protagonists find that even their memories about the same event are quite different, shaped by the intervening experiences. Basically it is the classic story of Ulysses returning to Ithaca.

My own experience doing field work in the Latvian countryside, recording the life stories of older Latvians, was much more positive, as I almost always used reciprocity and we often ended up with a partial exchange of stories and experiences. (See Hinkle 2001; 2003; The Oral History Review 2003, 23-113; Rouverol 2003.) I found that if we, diaspora interviewers, came to Latvian Latvians with an honest and sincere desire to understand their experiences, and if we allowed enough time for trust to grow, then we achieved a true exchange of stories and experiences. But we, the interviewers, had to earn it. Trust in an interview situation usually came with time, with discussion and with an exchange, as it probably would in a social setting.

\section{Diaspora Latvians AND IsSUES OF IDENTITY}

\section{The Latvian language}

Since Latvians on both sides of the ocean share the same language, one would expect it to be a unifying factor, but it is not necessarily so. There seem to be three aspects that have created problems: the different attitudes of people toward the language; the content of what is said (i.e., the meaning of words); and the communication style.

For diaspora Latvians the Latvian language has been central to their Latvian identity; it has been maintained and passed on to the next generations with great effort and sacrifice of time and material. Even now, fifty-four years after entering the United States, the overwhelming majority of large and small gatherings and publications are in the Latvian language. "I have always loved the Latvian language", Vija Zuntaka-Bērziña explained (Interview of Vija Zuntaka-Bērziņa, 2003). As Austris Grasis observed: “[..] Just think of the language. How many languages do you know where you can say Dievinsš, 'Little God' in English! It sounds ridiculous. There is no such diminutive form." (Interview of Austris Grasis, 2003.)

Many diaspora Latvians often feel that Latvians in Latvia do not value the Latvian language enough. Our authors often comment negatively about the prevalence of Russian and the Latvian tendency to switch to Russian whenever a Russian-speaker enters, even when the latter understands Latvian. Here we also have to remember the distinct feeling of obligation, that many of our authors expressed, to maintain a pure and correct Latvian language because it was being distorted and suppressed in Soviet Latvia. 


\title{
MAJJA HiNKLE
}

Another source of misunderstandings between Latvian and diaspora Latvians has been that certain words are culture-specific; they have significant meanings that are not understood by members of the other culture. Jānis Gobinsš gave the following example:

\begin{abstract}
In my dealings with my Latvian colleagues I eventually noticed that they always finished the conversation with a very specific expression - "nu tad sarunats" ["well then, it is agreed']. I don't normally use that expression, "sarunäts". We talk about it, we decide what to do and then it happens. But with my Latvian colleagues it often happened that I thought that we had agreed to do something, but we actually hadn't, we had only talked about it. And eventually I understood that the word "sarunats" is the magic word, which is essential for both sides to feel that it really has been mutually agreed upon. (Interview of Jānis Gobinsš, 2003.)
\end{abstract}

In addition, Americans, and by now also Latvian-Americans, try to be as direct in their communication as possible, whereas in Latvia the real meaning is often in the subtext. Again Jānis Gobiņš: "People read between the lines. What misunderstandings I have had because of that at work! I couldn't even communicate by e-mail with the person whom I had appointed to head [Radio-]SWH, everything was totally misunderstood and misinterpreted, absolutely and totally!” (Interview of Jānis Gobiņšs, 2003.)

\section{Social manners, interpersonal relationships, ethical concerns}

Some of our respondents criticized the societal and cultural norms in Latvian society. For instance, Maija Medne noted that:

The first time that I went to Latvia, all that shoving! How people shoved each other, pushed each other, spat on the street, I don't know what else! I came back and went to MacDonald's, and there the girl [behind the counter] said: "Thank you, have a nice day!" Tears started streaming down my face. [..] Well, one doesn't need to smile all the time, but good God, you could at least say: "Thank you!" [..] I like to smile. I myself, when I am in a bad mood, I smile a little. No kidding, I feel better. (Interview of Maija Medne, 1998.)

Others recognized that perceived slights and rudeness in Latvia sometimes are simply the result of different societal norms in Latvian and diaspora societies. Jānis Gobiņ̧̌̌ observed that:

We often see among returning Latvian-Americans a very open contempt for Latvian Latvians for such trivial, superficial things as not saying "thank you", for example.

[..] Those people are not impolite; they simply bave a different attitude toward the 


\title{
Latvian-Americans in the Post-Soviet Era
}

same thing, a different societal norm. A Latvian will look at an American girl who smiles all the time, and he'll say: "what's she smirking about?" (Interview of Jānis Gobinšs, 2003.)

A more serious problem has been the perception and sometimes also experience by some émigrés that in Latvia one always needs to use bribes and that the concept of honesty, especially in business or governmental dealings, is much less stringent than in the West. Jānis Gobiņš again:

Here in the Soviet Union a generation has grown up who have a completely different concept about honesty, [..] a totally different concept about integrity and ethics. That is a basic barrier why Western Latvians have difficulty interacting and integrating with Latvians in Latvia. [..] But in a way I also understand the Latvian businessman, whom I would characterize as dishonest from a Western perspective. I also regard him as partially positive, because that is actually necessary to make ones mark in this huge mass. They stand out; they are on the borderline between honest and dishonest. So each negative also has a positive aspect. (Interview of Jānis Gobiņš, 2003.)

When I presented the findings of this article for the first time at a Latvian cultural immersion camp for adults in 2004, this point elicited the most heated discussion, because it is difficult for émigré Latvians to recognize that they, too, have acquired "non-Latvian" characteristics and attitudes. While people in Latvia adopted Soviet culture, the émigrés became more and more American and both have ended up quite different from one another.

\section{KinSHIP AND ANCIENT LATVIAN CULTURE}

A further factor seems to be a special feeling of kinship with all Latvians, a love of all things Latvian, that doesn't seem to be present in Latvian society in Latvia. When I asked Jānis Gobiņš what had kept him connected to his Latvian identity, he said:

\begin{abstract}
More or less a tremendous, indescribable love for the Latvian nation and Latvia. It absolutely cannot be formulated in words. I don't think that it is tied to any kind of culture, or, I don't know, it's simply that every Latvian is dear to me, no matter who he is. It's very hard. The first time when we met Latvian Latvians in an American airport, you immediately want to go up to them, and say: "bey, a Latvian, how fantastic!" And you see right away that there is a wall there somewhere, that he has absolutely no interest in it. (Interview of Jānis Gobinš̌, 2003.)
\end{abstract}

Clearly, the scarcity of Latvians in the West enhances our pleasure at meeting one. 


\section{MAJJA HINKLE}

One of the major cultural values that the refugees of Second World War brought with them as they fled their homes was their specifically Latvian culture: traditions, songs, festivals, spiritual values, and sometimes even material culture - folk costumes, jewelry, ethnographic books. (Interview of Maija Medne, 1998.)

This traditional culture remained throughout the exile period not only as a powerful tool for maintaining one's Latvian identity, but also as a means of saying to the surrounding American community that here is our culture, all that is specific and dear to us. For example, many Latvian homes are decorated with Latvian traditional textiles. Some narrators mentioned bringing Latvian food to their colleagues during holidays. Furthermore, all larger American cities hold annual ethnic festivals, where Latvians often participated with the other nationalities, to sell their traditional foods and to demonstrate Latvian folk dances. These festivals showed Americans traditional Latvian culture, strengthened Latvian unity, and helped young people develop pride in their heritage.

In Latvia, on the other hand, old traditional culture could be hard to find even in such important traditional festivals as the midsummer night Jäni festival. Some, especially members of folklore groups, have tried to remedy this, among them Austris Grasis, an émigré and a Baltic language professor from the University of Bonn. For five years, Grasis has celebrated a traditional Jāņi on his farm in Mazsalaca, which attracts revelers from all over Latvia and abroad. He explained that

\section{Janni has deep roots in our culture. Everybody who has ever tried to celebrate a tradi- tional Janni understands their deeper meaning, and realizes its magic, the power that is in it. He will also understand that it needs to be done for oneself, not to show off. [..] The young people from my village said that they hadn't known how interesting such a Jani could be, to celebrate it in that [traditional] way. (Interview of Austris Grasis, 2003.)}

In this regard, it is noteworthy that during the last few years folklore groups across Latvia have made a concerted effort to educate and interest people in Latvian Jāņi traditions.

Another example of how the émigré community developed Latvian traditional culture much more broadly, and some would say, more authentically, than in Latvia concerns the Latvian traditional stringed instrument kokle. As the émigré musician, composer and conductor Andrejs Jansons has observed, "There was a period when all statistical data showed more kokle players in the United States than in Latvia" (Interview of Andrejs Jansons, 1999).

In saying this I do not seek to imply that traditional culture in Latvia did not exist, only that traditional Latvian culture was emphasized more in exile than it was in Latvia, and it is this aspect that some émigrés have found missing in contemporary Latvia. (5) The emphasis on traditional culture in émigré societies is not unusual. Ayumi Takenaka, for example, has described how, over several generations, Peruvians of Japanese descent have maintained cultural traditions and values that are no longer present in Japan. (Takenaka 1999.) 


\section{Latvian-Americans in the Post-Soviet Era}

As with all the cultural aspects and differences that I have discussed, the situation here is also dynamic and changing, as Latvia continues to adjust and, to some extent, adapt to Western European culture and both sides come to accept each other and appreciate differences without criticism and denigration. The comments and reactions that I have described in this paper are representative of the period between 1997 and 2003, and probably do not accurately reflect the evaluations that we would get today. To uncover one indication of possible changes in émigré attitudes toward Latvia, I did an informal survey in my August 2005 "Exile History" workshop. Of the approximately forty participants only one admitted that he still felt unaccepted and unwelcome in Latvia, whereas in 1998 lack of acceptance was a common complaint. ("Exile History" workshop, August, 2005, Catskills, NY; also Bela-Krūmiņa 2005.) Either lack of acceptance has become a non-issue or the group setting inhibited negative comments.

\section{Émigré culture and longing for home}

The final cultural element which keeps some diaspora Latvians from feeling at home in Latvia derives from the fact that the culture that has developed within the diaspora is not only very rich and interesting, but was created by the émigrés' own efforts and work. It thus "belongs" to the émigrés, who knows it and understands it. In the words of Lidija Bālēna:

My real home is in Flushing [NY], [..] where I live. [..] When they bought the land here [in the Catskills], I immediately joined in. I worked with the trees, logged the woods. There, where the woods were cleared, we went to belp cut up the branches. Then we cleared the pond; we went with rakes. It was hard work, but we did it. We went almost every weekend, I couldn't take it any more.

[..] Latvia lives for me only in my imagination and my thoughts, not in reality. There is nothing from the past there, all is new. [..] When I returned to Latvia for the first time, in ninety-two when I first went back to my home, the place where I was born, I didn't recognize anything there, nothing. Not even the path on which we walked. I found the foundation of the house. Within the foundation, about the place where my bed had been, there now was a fir tree. Some of its cones had dropped to the ground. I took three fir cones with me, that is all that I took from my father's house.

I have lived my life [here in the United States]. I am very sorry, there is my birth country [dzimtene], but this is my home. (Interview of Lidija Bālēna, 2000.)

It is noteworthy that some of the older members, who had been most active in the diaspora community, feel more at home in the émigré culture to which they themselves have contributed significantly than in the culture in Latvia. But it is just as significant 


\title{
MAJJA HiNKLE
}

that many still-active members of the diaspora community have found ways in which to reconcile their allegiance to Latvia, while continuing to live in the United States. For example, Miervaldis Janšēvics:

\begin{abstract}
Even though I live here, I often go to Latvia. I feel very comfortable in Latvia, in two weeks I don't have any problems. [..] I can accomplish a lot there. But I have a lot to do here, too; I can't give it all up. Where is my home? My home is wherever I am. (Interview of Miervaldis Janšèvics, 1998.)
\end{abstract}

\section{Participation in Latvia’s development}

Many of our narrators describe activities that they have undertaken to help Latvian cultural, economic or political development, while continuing to live in the United States. The activities can broadly be categorized into two types: those that bring Western resources, institutions and expertise to Latvia and those that bring Latvian professionals, students or culture to Western countries.

In the first type of activity the most common category of helping has been to invest funds in Latvian development, be it as simple as renting or renovating an apartment, helping relatives upgrade a farmstead, or as complex as founding a company or creating a granting agency for social or cultural projects in Latvia. Some narrators have enlisted foreign governments or international or transnational Latvian organizations to finance or sponsor projects in Latvia. For example, Miervalids Jansevics, a member of the Rotary club, encouraged Rotary clubs from four nations to cooperate in building a small, modern hospital in the rural city of Auce (Interview of Miervaldis Janševics, 1998), while Ruth Whittaker was a leading participant in the Canadian government-sponsored cleanup of the Barta rocket base (Interview of Ruth Whittaker, 2003). Thirdly, a number of émigrés have worked or volunteered in Latvia, often also being the ones who found and organize the activity. For example, Ingrida Mieme organized a very popular summer camp along the lines of LatvianAmerican summer camps (Interview of Ingrida Mieme, 2002), while a number of oral historians have been regular volunteer interviewers in the Field Work Program of the University of Latvian's Oral History Project. (See Hinkle 2001.)

A number of émigré Latvians have sponsored opportunities for Latvian professionals, students, artists or musicians to either study or perform abroad. For example, Juris Vīksninsšs, Professor of Economics at Georgetown University, was the administrative director of a summer program in banking, finance and economics during the crucial first years after the collapse of the Soviet Union. The program was attended by a number of young Latvians, who went on serve in leading positions in the government. (Interview of Juris Vīksniņš̌, 2003.) Finally, as Jānis Gobiņš pointed out from his own experience while working at the Siemens company in Munich, Germany, Latvian-Americans can act as interpreters in a work situation between the 
Latvian and American cultures, because with some experience they are in a position to understand them both. Thus one can be an active participant in Latvian affairs without returning to live there.

\section{SUMMARY}

The American Latvian Association's Oral History collection contains about 220 life stories, mostly from refugees from World War II or their descendents. One of the basic themes in the stories is the relationship of Latvian-Americans to Latvia and Latvian culture. People fled Latvia mainly to escape the returning Russian army and the war, but with the thought that they will soon return home. Displaced Person's camps in Germany enabled Latvians to form social and institutions networks, as well as formulate a narrative of what it means to be a Latvian abroad. After emigration to the United States, many formed still active communities-in-exile. They stayed connected to their Latvian roots and communities because of a deep sense of responsibility toward Latvia, the feeling of being the true voice of an occupied, oppressed people; practical help from the community; feeling more comfortable in Latvian culture than American, and the possibility of attaining leadership positions in Latvian society. Even though no one gave negative reasons for remaining in Latvian society, group discussions revealed painful memories caused by rejection, demands for conformity to an ideal Latvian émigré identity, and deep divisions within the community with respect to Soviet Latvia.

Although the theme of "returning to Latvia" continued throughout the years of the diaspora, relatively few people returned after Latvia regained its independence in 1991. The main reasons have been practical, for instance family in the United States and health. More complex reasons are the perception of not being accepted in Latvia, and cultural differences between Latvian and diaspora Latvians, including language (attitude toward it, meaning of words, communication style); societal norms, manners, value systems; emotional attachment to all things Latvian; traditional Latvian culture; and investment in and familiarity with émigré culture. The perceptions by members of both communities of cultural differences between them are dynamic and changing. The older formerly active members of the émigré community find it the hardest to accept present-day Latvia, whereas the still active members have devised various ways of participating in Latvian development while continuing to live in the United States. 


\section{MaIJA HinKLE}

\section{Notes}

1. For studies of immigration in the United States, for example, see American Behavioral Scientist [1999]. For the policies and practices of return migration in Europe see "Return Migration: Policies and Practices in Europe" in IOM International Organization for Migration, January 2004.

2. Of the 200000 about 30000 were soldiers, several thousand were mobilized or volunteered to work in Germany, and most of the rest were refugees. Only about 100000 eventually reached Germany. Baltais (1999) suggests that during the war about 217000 Latvians had reached Germany, but only about 140000 remained as émigrés.

3. In August, 2005, I started interviewing the parents of children who attend the English language Latvian camp in the Catskills, and their responses have been much more varied.

4. The community was divided into two large camps, with one side, particularly the "Daugavas Vanagi" organization and the central Latvian organizations in Canada, declaring that all contact with Soviet Latvia was treason. This included travel to Soviet Latvia (since it required the request for a visa through the authorities in Moscow), reading literature published in Soviet Latvia, sponsoring or hosting Soviet performing artists to the United States, viewing Soviet Latvian films, or even welcoming Soviet Latvian cultural or religious figures in ones home. Communities differed in the severity of restrictions, reactions and the vitriol that was heaped upon the "transgressors", with Toronto in Canada being perhaps the most divided and extreme. Some narrators, who had supported and participated in contacts with artists in Soviet Latvia or traveled to Soviet Latvia, talked about it freely and recounted the repressions that followed. (See especially the interview of Valija Runge, 1998; Liepinšs 2004.) In my workshop on "Exile History" in the Catskills 3x3 cultural immersion camp in August, 2005, the participants talked for several hours about their own experiences with repressions and discussed the far-reaching, negative consequences of the intolerance both for the émigré communities and for their relationship with the people in Latvia. No one described being among the advocates of no contact, perhaps because they didn't want to own up to it, or perhaps we haven't succeeded in speaking with any of the perpetrators of repressions.

5. The situation with traditional culture in Latvia and in exile is complicated. When looking at traditional culture in Soviet Latvia, we have to differentiate between the official Soviet policy which by and large tried to fit the culture into a simplified, sometimes even "kitschy" mold and which at one point even prohibited the Jāñi celebrations, and the efforts of individual traditional artists and musicians to explore and practice authentic folk traditions. Moreover, while émigrés sometimes criticize the traditional culture in both Soviet and present-day Latvia, some Latvians look upon émigré emphasis on traditional culture as hypocritical and exaggerated. (See especially interview of Ojārs Rubenis, 2003.) 


\section{Latvian-Americans in the Post-Soviet Era}

\section{REFERENCES}

\section{Archival material}

The American Latvian Association, Oral History Project. University of Latvia, Riga.

Discussion groups in cultural immersion camps in the Catskills, NY, USA (a week long workshop on "Exile History"), and Smiltene, Latvia, and in oneday training seminars in Boston, Chicago, "Kursa" (Shelton, WA), New Jersey, Washington, DC. Interviewers: Biruta Abula, Gunta Harvey, Maija Hinkle, Rita Petričeka, Dzidra Ziedonis.

— Ādolfs Ābele, November 1999, Los Angeles, CA.

— Lidija Bālēna, August 2000, Catskills 3x3 camp, Elka Park, NY.

- Rita Drone, June 2005, Riga, Latvia.

- Baiba Dumpe, [several times] 1999-2001. Kalamazoo, MI.

- Jānis Gobiņš̌, November 2003, Riga, Latvia.

- Austris Grasis, August 2003, Catskills 3x3 camp, NY.

- Andrejs Jansons, August 1999, 3x3 camp, Catskills, NY, USA.

- Miervaldis Janšēvics, July 1998, Sheldon, WA.

- Kārlis Ķuzulis, September 2000, Washington, DC.

- Kārlis Kuzulis, October 2000, Rockville, MD.

- Maija Medne, August 1998, Catskills 3x3 camp, Elka Park, NY.

— Ingrida Mieme, August 2002, Catskills, NY.

- Isabella Osìte, June 1999, California.

— Ojārs Rubenis, August 2003, Catskills, NY.

— Valija Rungge, March 1998, Kalamazoo, MI.

— Juris Vīksniņš, August 2003, Catskills, NY.

- Ruth Whittaker, August 2003, Catskills, NY.

- Dzidra Ziedone, August 1998, 3x3 Camp, Catskills, Elka Park, NY.

- Vija Zuntaka-Bērziņa, August 2003, Catskills 3x3 camp, NY.

\section{Literature}

American Behavioral Scientist 1999: 42(9).

BALTAIS, MIRDZA KATE 1999: Piespiedu iesaukšana darbam Vācijā, militāram dienestam un evakuācija uz Vāciju. - Ezergailis, Andrew (ed.), The Latvian Legion: Selected Documents. Toronto: Amber Printers and Publishers.

BELA-KRŪMIÑA, BAIBA 2005: Narrated Memories: the Past in the Present. - The Baltic Way in Europe. Revolution and Evolution. 6th Conference on Baltic Studies in Europe, abstracts. Valmiera, 17-19 June 2005. 
CARPENTER, INTA GĀLE 1990: A Detour through America: the Latvian Émigré Experience in Jānis'Jaunsudrabinsš' Tà mums iet. - Metuzale-Kangere, Baiba \& Rinholm, Helge D. (eds.), Symposium Balticum. Hamburg: Zhelmut Buske Verlag. - 2006: Festival as Reconciliation: Latvian Exile Homecoming in 1990. - Journal of Folklore Research 33(2).

CARPENTER, INTA GĀLE 1996: Festival as Reconciliation: Latvian Exile Homecoming in 1990. - Journal of Folklore Research 33(2).

CASSARINO, JEAN-PIERRE 2004: Theorizing Return Migration: the Conceptual Approach to Return Migrants Revisited. - IJMS: International Journal on Multicultural Societies 6(2): 253-279.

CLARKE, MARY MARSHALL 2002: Oral History: Art and Praxis. - Adams, Don \& Goldbard, Arlene (eds.), Community, Culture and Globalization. New York: The Rockefeller Foundation.

HINKLE, MAIJA 2001: Talcinieki mutvārdu vēstures projektos Latvijā un trimdā. - Spogulis 2001: 18-30.

— 2003: ALAs mutvārdu vēstures vākšanas projekts un trimdas identitāte Amerikas latviešu dzìvesstāstos. - Latvijas Vèstnesis, 19. un 20. jūnijs 2003.

- 2005: American Latvian Association's Oral History Project "Exile Life Narratives"

- Zirnite, Mara \& Hinkle, Maija (eds.), Oral History Sources of Latvia. History, Culture and Society through Life Stories. Riga: Latvian University.

KIRSS, TIINA 2003: Memory Slices: Life Story Elicitation Through Writing Groups Among Estonians in Toronto. - The Role of Oral History in Shaping Cultural and Personal Identity. International Conference. Program Abstracts. Riga, 2003.

KUNDERA, MILAN 2002: Ignorance. New York: NY, HarperCollins Publishers. LIEPIN̦Š, GUNTIS 2004: Cultural Exchange between Latvia and North America 1967-1990. - Konference "Trimda, kultūra, nacionālà identitäte" referätu kräjums. Nordik, 1-3 October 2004.

THE LATVIAN NATIONAL ORAL HISTORY PROJECT 2006 [online]. <www. dzivesstasts.lv> [2.4.22006.]

THE ORAL HISTORY REVIEW 2003 [Special Section: Shared Authority] 30(1): 23-113.

PLAKANS, A 1995: The Latvians, a Short History, Stanford, CA: The Hoover Institution.

ROSENWALD, G. C. \& OCHBERG, R. L. 1992: Introduction: Life Stories, Cultural Politics andSelf-Understanding. - Rosenwald, G. C. \& Ochberg, R. C. (eds.), Storied Lives: The Cultural Politics of Self-Understanding. New Haven: Yale University Press.

ROUVEROL, ALICIA J. 2003: Collaborative Oral History in a Correctional Setting: Promise and Pit-falls. - The Oral History Review 30(1): 61-85.

TAKENAKA, AYUMI 1999: Transnational Community and Its Ethnic Consequences. - AMERICAN BEHAVIORAL SCIENTIST 42(9): 1459-1474. 
VON PLATO, ALEXANDER 1998: Oral History in Germany after National Socialism and Real Socialism - The Role of Oral History in Shaping Cultural and Personal Identity International Conference. Program abstracts. 2003. Riga, 2005.

WYMAN, MARK 1998: DP - Europe's Displaced Persons, 1945-1951, Ithaca: Cornell University Press.

ZIRNITE, MARA \& HINKLE, MAIJA (eds.) 2003: Mutvārdu vēstures avoti-Dįivesstāsti vèsturè, kultūrā un sabiedribā. Ižlase. Riga: Latvian University. [2004]

- (eds.) 2003: Oral History Sources of Latvia. History, Culture and Society through Life Stories. Riga: Latvian University. [2005]

PhD Maija Hinkle is a coordinator of the American Latvian Association Oral History Project. 